Vol 3, No. 1, Agustus 2020: 235-240, DOI: https://doi.org/10.34007/jehss.v3i1.2485

\title{
Perceived Peer Support, Autonomy and Self-Esteem Among Boarding School Students
}

\author{
Nurul Hidayah1)* \& Mohammad Sahari Nordin'2)
}

1) Faculty of Education/ Education, Sekolah Tinggi Agama Islam Negeri Teungku Dirundeng Meulaboh, Aceh, Indonesia

2) Faculty of Education/ Education, International Islamic University, Gombak, Malaysia.

Submitted: 12 August 2020; Accepted: 15 August 2020; Published: 17 August 2020

*Coresponding Email: nurulhidayah@staindirundeng.ac.id

\section{Abstract}

This study conducted to investigate perceived peer support and autonomy among boarding school students and its correlation with their self-esteem. Among 131 students from two selected boarding schools been the participant of this study. The researchers applied quantitative method in collecting data. The questionnaire adopted for this research was developed by Yueming Jia et al, (2009) and Way et al. (2007). The data showns that boarding school students perceived high level of peer support and autonomy. This due to amount of time they spend together in school hours and in the dormitory. They got the chances to to get involved in the decision-making process of the school like school regulation, teaching-learning activities and sports among classes. However, the study also found that there is no correlation between perceived peer support, autonomy and boarding school students' self-esteem. This finding contradicted former studies which shows that social interaction with peer partly affect students' mental health and self-esteem.

Keywords: Peer Support, Autonomy, Self-esteem, Boarding School Students

How to Cite: Hidayah, N, Sahari Nordin, M. (2020). Perceived Peer Support, Autonomy, and Self-esteem among boarding school students. Journal of Education, Humaniora and Social Sciences (JEHSS). 3 (1): 135-240.

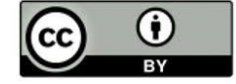




\section{INTRODUCTION}

In this paper, we investigated the correlation between peer support and autonomy with boarding school students' self-esteem in Aceh, Indonesia. Peer support and Autonomy is one of many school climate elements. According to school Reddy, Rhodes and Mulhall (2003), perceived school climate affects students' self esteem. They further argued that students who feel rejected by peer might have a low score of self-esteem, while students' who feel accepted by peer have a high score of self-esteem. In addition, senior high school students aged 16-18 years old are categorized as adolescents who are undergoing the identity searching phase in their lives and experience turbulent period of a human life (Way, Reddy \& Rhodes, 2007). Therefore, they do need peer support and autonomy, as well as hight score of self-esteem in strunggling the turbulent period.

Furthermore, students who experience the decrease of peer support will also experience a decline in self-esteem and an increase in depressive symptoms (Jia, Ling, Chen, Hughes, Ke, and Lu, 2009). Therefore, educationalist should pay more attention on perceived peer support and autonomy in teaching and learning procces, as well as students' psychological adjustment. Students perceiving negative school climate such as a low level of peer support and autonomy but scoring high on self-esteem will more likely to get involved in bullying ( Gendron, Williams \& Guera, 2011). They further explained that students perceiving positif school climate such as a high level of peer support and autonomy will less likely to get involved in bullying. Additionally, if the students' perceived low level of peer support and autonomy, they are more likely to skip teaching and learning process, to become unmotivated student and to have behavioral problems. As the result, we would like to examine students' perception of peer support and autonomy and to investigate the correlation between Peer Support and Autonomy with Students' self-esteem.

In order to create positive school climate, peer support and autonomy students perceived during school hours, as well as students' self-esteem are important subject to studied. It might result to higher motivation and higher academic achievement. For parents, it will the confident in nurturing their children choosing the community or school for children development. peer support and autonomy which means the extent to which students enjoy team-work and get the chance to make decisions or to voice their opinion in the school (Way et al., 2007). Some researchers point out that peer relationships are positively correlated with middle school students' psychological and behavioural adjustments. Urberg, Luo, Pilgrim and Degirmencioglu (2003) argue that the acceptance of peers may result in adolescents' adaptation to conform to their peer's behaviours.

Additionally, according to G.H Ramsdal, (2008), Self-Esteem is defined as the answer to the question "Who are we?" and "what we do?". In this study, self esteem defined as how a student perceive himself/herself confidence in thinking and dealing with problems. As the result, it defined either positive or negative attitudes that students hold toward theirselves.

Several scholars have described the definition of self-esteem. According to Rosenberg (1965), self esteem is defined as either the positive or negative attitudes that an individual hold towards himself. According to Murberg and Bru (2004), adolescence is a transition period in which adolescents experience changes in terms of physiological, cognitive and social life. Senior high school students are considered as adolescents who are 12-19 years old, therefore, they experience those changes. Jackman and MacPhee (2015) found that adolescents' self-esteem partially mediated the future orientation and future risk behaviours. It plays a role as protective factor against adolescents' involvement in risky behaviours. Furthermore, Adam et al. (2006) state that self-esteem has a great role in one's development since it is considered as an important maker of general well being. In addition, Boyd and Bee (2015) argue that high self-esteem is related with positive development outcome such as the ability to be a person that is able to resist peer pressure, get high grades at school, and rarely depressed. In short, psychological adjustment during adolescence has significant relationship with adolescents' future life.

Interestingly, Zhang et al. (2012) state that social interaction with peer partly affect students' mental health. Peer victimization, for instance, leads to either physical or verbal bullies. This kind of negative peer relationship is associated with the increase of psychopathology. Furthermore,

wiw http://mahesainstitute.web.id/ojs2/index.php/jehss

‥ mahesainstitut@gmail.com

236

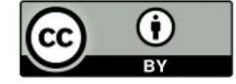

This work is licensed under a Creative Commons Attribution 4.0 
Gendron, Williams and Guerra (2011) support this by arguing that school climate including peer relationship moderate bullying perpetration among students. Therefore, peer relationship not only affects students' academic achievement but also students' psychology.

In terms of students autonomy, Yueming Jia et al. (2009) reported that Chinese students perceived higher opportunity for autonomy compared to American Students. In the classroom, Chinese students have several chances to get involved in the decision making process about school regulation, and teaching-learning activities. Furthermore, they also gain the chance to arrange several sport matches among classes and assist teachers in handling some group discussions. Those kinds of opportunities rarely happen among American students. Interestingly, that kind of autonomous students-expression and decision making are the requirement for successful students development (Roeser et al., 2000 as cited in Yueming Jia et al., 2009). To sum up, peer relationship or peer support as well as autonomy really determine either positive or negative perception of the school climate and do affect students' development.

There are several senior high schools both boarding and non-boarding schools in Banda Aceh, Indonesia. Some researched studied the effect of peer suport on several psychological aspect among nonboarding school students. This research pay more detail on the effect of perceived peer support and autonomy on boarding school students' self-esteem. Boarding school students spend a large amount of time with their peers, teachers and active in severals on going activities in the dormitory (Papworth \& Ginns, 2016). It probably provide chance to build personal realtionship among school members; friends and teachers. Therefore, the researcher would like to investigate peer support and autonomy perceived by boarding school students' and it correlation with their self-esteem.

\section{RESEARCH METHODS}

A quantitative cross sectional is the method applied this study to answer the research questions. Banda Aceh, Indonesia, is area of this study. The students of two selected boarding schools are respondents of the study which consisted of 131 students from grade 3 majoring both social science and natural science. The researcher adopted the questionnaire developed by Way et al. (2007) and Yueming Jia et al (2009) in collecting the data.

The items of the questionnaire are categorized as peer support and autonomy, and selfesteem. The data collected were analyzed by using the SPSS (Statistical Package for Social Science) software package. Two procedures used namely descriptive analysis and pearson correlation.

\section{RESULTS AND DISCUSSION}

In this study, the firs research question was perceived peer support and autonomy among boarding school students. Boarding school students' responses are presented in the table 1.

Table 1 Distributions of Boarding School Students' Responses

\begin{tabular}{|c|c|c|c|c|}
\hline \multirow[t]{2}{*}{ No. } & Items & \multicolumn{3}{|c|}{$\begin{array}{l}\text { \% of Boarding School } \\
\text { Responses }\end{array}$} \\
\hline & SA \& A & & $\mathbf{N}$ & SD \& D \\
\hline & Peer Support and Autonomy & & & \\
\hline 1. & Students in this school felt that they need each other. & 80.1 & 14.5 & 5.3 \\
\hline 2. & Students in this school get to know each other really well. & 77.9 & 16.8 & 5.3 \\
\hline 3. & There are some students who select other students to be their friends. & 47.3 & 31.3 & 21.4 \\
\hline 4. & Students get to help decide some of the rules in this school. & 43.5 & 37.4 & 19.1 \\
\hline
\end{tabular}

Majority of the boarding school students felt that they need each other (80.1\%). In addition, $77.9 \%$ of the students confirmed that they get to know each other really well. This was followed by two items respectively in which they agreed that there are some students who select other students to be their friends (47.3\%), and they get to help decide some of the rules in this school (43.5\%). However, there are also some students who disagreed with the items measuring peer

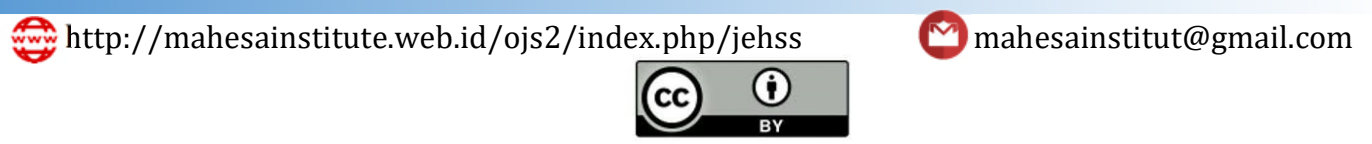

237

This work is licensed under a Creative Commons Attribution 4.0. 
support ranging between $5.3 \%$ and $19.1 \%$ of them. The overall finding shows that majority of the students perceived high peer support and autonomy with the average agreement at $62 \%$.

Secondly, the correlation between peer support, autonomy and students' self-esteem are preseanted in the table below;

Table 2 Correlation Matrix

\begin{tabular}{|c|c|c|c|}
\hline & & Self-Esteem & Peer Support \\
\hline \multirow[t]{2}{*}{$\overline{\mathrm{SE}}$} & Pearson Correlation & 1 & \\
\hline & Sig. (2-tailed) & & \\
\hline \multirow[t]{2}{*}{ PS } & Pearson Correlation & .143 & 1 \\
\hline & Sig. (2-tailed) & .104 & \\
\hline
\end{tabular}

Note: *statistically significant at $\mathrm{p}<0.05$ level, PS = Peer Support and Autonomy, SE $=$ Self-Esteem.

The data shows that among the boarding school students, there was no significant correlation between peer support and self-esteem in which correlation coefficient indicates $\mathrm{r}=$ 0.143 and $p$ value $=0.104$, which means $p=0.104>0.05$.

To sum up, majority of boarding school students reported that they received more peer support and autonomy. This finding is in line with Yueming Jia et al. (2009) study which showed that the amount of opportunities students have to interact with classmates enhance the feeling of peer support. Boarding school students interact with their classmates all day. Furthermore, boarding school students have many chances to get involved in the decision-making process of the school like school regulation, teaching-learning activities and organizing extramural activities and sports among classes. However, the significant level of peer support had no correlation with students' self esteem. This result contradicted a study conducted by Zhang et al. (2012) which reported that social interaction with peer partly affect students' mental health. Peer victimization, for instance, leads to either physical or verbal bully. They further argued that negative peer relationship is associated with the increase of psychopathology. Hence, for these students, peer support has no relationship with their self-esteem. This finding also was not in line with the idea of Bint-E Tahir, Inam and Raana (2015) who reported that there was a significant relationship between social support and self-esteem.

\section{CONCLUSION}

Boarding school students perceived high level of peer support and autonomy. They spend the amount of time together and have the opportunities to interact with classmates hence it enhance the feeling of peer support. Boarding school students interact with their classmates all day, not only in the classroom but also in the residence or dormitory. Furthermore, boarding school students have many chances to get involved in the decision-making process of the school like school regulation, teaching-learning activities and sports among classes. However, there is no correlation between perceived peer support, autonomy and students' self-esteem. This finding contradicted former studies which show show that social interaction with peer partly affect students' mental health and self-esteem.

\section{REFERENCE}

Ahmed, M. A., \& Oliver, N. E. (2017). Comparison of Boarding and Day Senior Secondary School Students' Performance in Biology in Owo, Ondo State, Nigeria, 4(3), 45-50.

Bint-E Tahir, W., Inam, A., \& Raana, T. (2015). Relationship between Social Support and Self-Esteem of Adolescent Girls. IOSR Journal Of Humanities And Social Science, 20(2), 42-46. http://doi.org/10.9790/0837-20254246

Boivin, M., Hymel, S., and Hodges, E.V.E. 2001. Toward a process view of peer rejection and harassment. Ins. Jaana J \& Sandra G (edit). Peer Harassment in School: The Plight of the vulnerable and victimezed. New York: The Guilford Press.

Gage, N. A., Prykanowski, D. A., \& Larson, A. (2014). School Climate and Bullying Victimization : A Latent Class Growth Model Analysis. School Psychology Quarterly 2014, 29(3), 256-271. American Psychological Association. http://dx.doi.org/10.1037/spq0000064 
Gendron, B. P., Williams, K. R., \& Guerra, N. G. (2011). An Analysis of Bullying Among Students Within Schools : Estimating the Effects of Individual Normative Beliefs, Self-Esteem , and School Climate. Journal of School Violance, 10, 150-164. http://doi.org/10.1080/15388220.2010.539166

Hashim, Rosnani (1998). Teachers training and work success: A case study of the effectiveness of the International Islamic University Malaysia (IIUM) diploma in education programme. Kuala Lumpur: Department of Education, IIUM.

Hoge, D. R., \& Hanson, S. L. (1990). School Experiences Predicting Changes in Self-Esteem of Sixth- and Seventh-Grade Students. Journal of Educational Psychology 1990, 82(1), 117-127. American Psychology Association, Inc 0022-0663/90/00.75

Jackman, D. M., \& MacPhee, D. (2015). Self-Esteem and Future Orientation Predict Adolescents' Risk Engagement. The Journal of Early Adolescence, 1-28. http://doi.org/10.1177/0272431615602756

Jia, Y., Konold, T. R., \& Cornell, D. (2016). Authoritative School Climate and High School Dropout Rates. School Psychology Quarterly 2016. 31(2), 289-303. American Psychology Association. http://dx.doi.org/10.1037/spq0000139

Jia, Y., Ling, G., Chen, X., Hughes, D., Ke, X., \& Lu, Z. (2009). The Influence of Student Perceptions of School Climate on Socioemotional and Academic Adjustment: A Comparison of Chinese and American Adolescents. Child Development, September/October 2009, 80(5).

Kounenou, K. (2010). Exploration of the relationship among drug use \& alcohol drinking, entertainment activities and self-esteem in Greek University students, 2(2), 1906-1910. http://doi.org/10.1016/i.sbspro.2010.03.1007

Loukas, A., Suzuki, R., \& Horton, K. D. (2006). Examining school connectedness as a mediator of school climate effects. Journal of Research on Adolescence, 16, 491-502.

Madjar, N., \& Cohen-malayev, M. (2016). Perceived School Climate Across the Transition From Elementary to Middle School. School Psychology Quarterly 2016, 31(2), 270-288. American Psychology Association. http://dx.doi.org/10.1037/spq0000129

Malley, M. O., Voight, A., Renshaw, T. L., \& Eklund, K. (2015). School Climate , Family Structure , and Academic Achievement: A Study of Moderation Effects. School Psychology Quarterly 2015, 30(1), 142-157. American Psychology Association. http://dx.doi.org/10.1037/spq0000076

Martin, A. J., Papworth, B., \& Ginns, P. (2016). Motivation, Engagement, and Social Climate : An International Study of Boarding Schools. Journal of Educational Psychology $2016.108(6), \quad 772-787$. http://dx.doi.org/10.1037/edu0000086

Martin, A. J., Papworth, B., Ginns, P., \& Liem, G. A. D. (2014). Boarding School, Academic Motivation and Engagement, and Psychological Well-Being: A Large-Scale Investigation. American Educational Research Journal, 51(5), 1007-1049. http://doi.org/10.3102/0002831214532164

Niyozov, S., \& Memon, N. (2011). Evolution of Themes, Continuities and New Directions Islamic Education and Islamization : Evolution of Themes, Continuities and New Directions, Journal of Muslim Minority Affairs Islamic Education and Islamization. (June 2013), 37-41. http://doi.org/10.1080/13602004.2011.55688

Rama, L., Sarada, S., (2017). Role of self-esteem and self-efficacy on competence - A conceptual framework. IOSR Journal of Humanities and Social Science, 22(2), 33-39. http://doi.org/10.9790/08372202053339

Reddy, R., Rhodes, J. E., \& Mulhall, P. (2003). The influ- ence of teacher support on student adjustment in the middle school years: A latent growth curve study. Development and Psychopathology, 15, 119-138.

Rigby, K. (2000). Effects of peer victimization in schools and perceived social support on adolescent wellbeing. Journal of Adolescence, 23, 57-68.

Roeser, R. W., Eccles, J. S., \& Sameroff, A. J. (2000). School as a context of early adolescents' academic and social-emotional development: A summary of research findings. The Elementary School Journal, 100, 443-471.

Sathyabama, B., \& Eljo, J. O. J. G. (2014). Family Environment and Mental Health of Adolescent Girls, 3(9), 4649. International Journal of Humanities and Social Science Invention ISSN (Online): 2319-7722, ISSN (Print): 2319-7714 www.ijhssi.org 3(9 September 2014), 46-49.

Shoshani, A., \& Steinmetz, S. (2014). Positive Psychology at School: A School-Based Intervention to Promote Adolescents' Mental Health and Well-Being. Journal of Happiness Studies, 15(6), 1289-1311. http://doi.org/10.1007/s10902-013-9476-1

Stover, D. (2005). Climate and culture. Why your board should pay attention to the attitudes of students and staff. American School Board Journal. 192(12), 30-32. 
Nurul Hidayah \& Mohammad Sahari Nordin, Perceived Peer Support, Autonomy, and Self-esteem among

Urberg, K. A., Luo, Q., Pilgrim, C., \& Degirmencioglu, S. M. (2003). A two-stage model of peer influence in adolescent substance use: individual and relationship-specific differences in susceptibility to influence, 28, 1243-1256. http://doi.org/10.1016/S0306-4603/02)00256-3

Wang, C., Berry, B., \& Swearer, S. (2013). The critical role of school climate in effective bullying prevention. Theory into Practice, 52, 296-302. doi:10.1080/00405841.2013.829735

Wang, W., Vaillancourt, T., Brittain, H. L., Mcdougall, P., Krygsman, A., Smith, D., \& Hymel, S. (2014). School Climate, Peer Victimization, and Academic Achievement: Results from a Multi-Informant Study. School Psychology Quarterly 2014, 29(3), 360-377. American Psychology Association. http://dx.doi.org/10.1037/spq0000084

Way, N., Reddy, Æ. R., \& Rhodes, Æ. J. (2007). Students' Perceptions of School Climate during the Middle School Years : Associations with Trajectories of Psychological and Behavioral Adjustmen. Am Journal Community Psychol 2007. 40:194-213. http://doi.org/10.1007/s10464-007-9143-y

White, N., Salle, T. La, Ashby, J. S., \& Meyers, J. (2014). A Brief Measure of Adolescent Perceptions of School Climate. American Psychological Association; http://doi.org/10.1037/spq0000075 